Jurnal Keperawatan Padjadjaran /Padjadjaran Nursing Journal

ISSN 2338-5324 (print)

ISSN 2442-7276 (online)

Online di http://jkp.fkep.unpad.ac.id

DOI : $10.24198 / \mathrm{jkp}$

\title{
The Effects of Sundanese Kacapi Suling “Ayun Ambing” Music Therapy to The Level of Anxiety on Chronic Renal Failure Patient Undergoing Hemodialysis
}

\author{
Mustopa Saepul $^{1}$, Laili Rahayuwati ${ }^{2}$, Chandra Isabella Hostanida Purba ${ }^{2}$ \\ Universitas Muhammadiyah Sukabumi, Faculty of Nursing, Universitas Padjadjaran \\ Email:ners_saepul@yahoo.com
}

Submitted: 24-7-2017 Accepted: 30-4-2018 Published: 30-4-2018

\begin{abstract}
One of the most common psychological problems found in patients with chronic renal failure (ESRD) undergoing hemodialysis is anxiety. Unresolved anxiety can have a negative impact on physiological and psychological conditions that can aggravate the condition of the disease. Traditional Sundanese music therapy Kacapi Suling "Ayun Ambing" has a slow tempo and soft so that it can be used as a therapy. The design used was a Quasy Experimental, with a pretest-posttest control group design approach, involved 46 patients divided into control groups (23) and intervention groups (23) taken by purposive sampling. The intervention group get given music a week 2 times with time 30 minutes for 2 weeks. Anxiety levels were measured using HARS (Hamilton Anxiety Rating Scale) before and after intervention. The control group received standard interventions provided by the Hospital. Data were analyzed by parametric and non-parametric test with Paired test, Independent test and Mann Whitney test. Differences of average before and after in two groups with the tested paired test showed no significant difference with $p$ value $<0.05$ whereas for differences in the average change of scores between the intervention and control group with independent $t$ test showed there was a significant difference with $p$ value 0.05 . An implication of this research and literature review were that Sundanese Kacapi Suling Music could be considered and applied as a complementary theraphy to decrease the anxety of client, particularly ESRD undergoing hemodialysis.
\end{abstract}

Keywords: Anxiety, Chronic Kidney Failure, Hemodialysis, Music Kacapi Suling. 


\section{Introduction}

The number of patients undergoing hemodialysis in 2014 worldwide reaches up to 1.5 millions, and around 60,000 patients die each year previously. The number is estimated to go up as the ratio of chronic kidney disease increases from $20-25 \%$. To pinpoint, the number of Indonesian patients undergoing hemodialysis reaches to 22,304 people in 2011, 24,524 in 2012, 27,782 in 2013 , and 28,882 in 2014, escalating $10 \%$ per annum. Let alone the fact that $60 \%$ of them are adults and the elderly, 2,476 of whom had died each year (Namawi, 2013; Sari \& Hisyam, 2015). The data were collected in the Medical Record and Hemodialysis Room at Regional General Hospital (RSUD) Syamsudin Sukabumi. The number of patients in the last 3 years increases by $2.5 \%$ : In 2013, 2014 , and 2015, the number of patients are 2,$593 ; 2,741$; and 2,760 ; in that order.

Hemodialysis is a form of therapy that replaces the function of chronic kidney failure in order to excrete toxic substance from blood and dispose excessive liquid. This therapy, surprisingly, causes some psychological problems such as anxiety, depression, and stress (Mahdav, Gorji, Yazdani \& Ardebil, 2013).

A research done by Macharon et al. (2014) in Lebanon, Beirut says that, out of 51 respondents, $50 \%$ of them experience anxiety, $45 \%$ depression, and 5\% suicidal thoughts. Cukor et al. (2008) did similar thing to 70 randomly chosen hemodialytic patients in America, showing that $45.7 \%$ of them experience anxiety and $40 \%$ depression. Meanwhile, Mollahadi, Tayyebi, Ebadi and Daneshmndi (2010) in Teheran, Iran claim that, out of 147 respondents, $63.9 \%$ experience anxiety, $60.5 \%$ depression, and $51.7 \%$ stress. Judging from these data, it is quite obvious that the number of occurences regarding anxiety problem over chronic kidney disease, remains high compared to other psychological problems like depression and stress. There are factors causing anxiety for these patients are pain while injection around the fistulae, hemodialytic complication, dependence on other people, difficulty maintaining job, financial crisis, fear of death, loss of sexual impulse or impotence, disrupted idea of self, role shift in family, and change in social interaction (Finnegan, Jennifer \& Veronica, 2013; Wang \& Chen, 2009).

Some actionable steps that the nurses can take is through collaboration and independent actions (Holly, Crosby, \& Carol, 2006). Independent actions include complementary therapy, that is hypnotherapy, relaxation tecnique, aromatherapy and intervention of music (Mahdavi, Gorji, Yazdani, \& Ardebil, 2013).

Patimah, Suryani, and Nuraeni (2015) lament that the relaxation technique, along with zikir (remembrance of Allah), is able to trigger relaxation response, therefore lowering the anxiety level. Meanwhile, Gorji, Davanloo, and Heidarigorji (2014) claim that the benson's relaxation technique can lower anxiety level, reduce pain and stress. Anastasia, Bayhakki, and Nauli (2015) state that providing aromatherapy through lavender inhalation after five minutes can lower the anxiety indicated by slow heart rate, the feeling of comfort, and relaxed state of mind. A research of Fauzi, Lestari, and Pranowowati (2016) conclusively believe that hypnotherapy proves significant effective to lower anxiety level of chronic kidney disease patients undergoing hemodialysis.

Another complementary therapy is music intervention, provided to patients based on their cultural background, passion, and religious belief. These interventions entail classical and traditional music (Martinez, 2009). Classical music, despite sounding unfamiliar for most Indonesians, proves useful to lower the anxiety level of the patients.

On the other hand, cultural factor and music's popularity will create more distractions and give a sense of relaxedness than unpopular music (Huang, Good, \& Zauszneiwski, 2010). One popular traditional music in Sunda is kacapi suling. The kind of music used for this research is the "Ayun Ambing" song, accompanied by the sounds of flute and harpischord. Based on the analysis result of Bapak Nanang (2016) from Universitas Pendidikan Indonesia, the song has $50-75 \mathrm{~Hz}$ frequency, 121 Kilobyte per second (Kbps), 76 desible with slow tempo, sung by the parahiyangan group.

"Ayun Ambing" was an effective choice 
Mustopa Saepul: The Effects of Sundanese Kacapi Suling “Ayun Ambing” Music Therapy

to lower anxiety level of the patients undergoing hemodialysis, compared to other complementary therapies. This is because the song is an auditorial trigger with distinctive stimulus for the hearing. The strings from guitar and the sound from the flute, intertwine beautifully, enabling the listener to express their feelings and oozing a sense of belonging. All of this result in a feeling of peace and a harmony of soul and body (Firman, 2012; Larasati, 2012).

The song is simple in terms of melodies and therefore popular among the Sundanese. It is ear-catchy for both patients and the nurses (especially when providing independent healthcare) (Kurdita, 2015). Moreover, such therapy is more affordable, and done by our client due to its invasiveness, and it requires no professional help like other complementary therapies (Damayanti, 2016).

This is proven by Supriadi, Hutabarat, and Monica (2015) who highlights that the song brings about a relaxing and peaceful effect, thus lowering the blood pressure. Lengga (2015) claims that the music, with $50-60 \mathrm{~Hz}$ frequency, made to listen to for 20-30 minutes to primary hypertension patients, reduces the systolic pressure and increases diastolic pressure. Other research on breast cnacer patients undergoing chemotherapy was done by Dian (2014), who claimed that around $16-40 \%$ patients in RSUP Hasan Sadikin Bandung vomit less on the intervention group than on the control.

The nurses play the role in providing healthcare to adult patients by noticing their Bio-Psycho-Socio-Spiritual aspect. Thus, it is hoped that the provided healthcare shall consider not only the patients's physical problems but also their psycho-socio-spiritual aspect.

That being said, it is necessary to conduct more research regarding the effect of therapy of kacapi suling music "Ayun Ambing" on the anxiety level of chronic kidney disease patients undergoing hemodialysis in the Hemodialysis Room at RSUD Syamsudin Sukabumi. The general purpose of this research is to identify the effect of therapy of kacapi suling music "Ayun Ambing" on the anxiety level of chronic kidney disease patients undergoing hemodialysis.

\section{Method}

This research applies a quasi-experimental design through pretest and posttest control group. Based on the total population in the 6 months period and previous research studies, the number of respondents is 46 patients undergoing regular hemodialysis therapy during 3 months data collection period. The samples were divided to 23 respondents on the intervention group, and the other 23 to control group using purposive sampling. The instrument used is music therapy, which is an MP3 (Music Player 3) file containing a Sundanese kacapi suling music called "Ayun Ambing".

The intervention' respondents were made to listen to it 2 times for 30 minutes total: 15 minutes before the the therapy and 15 minutes after. The data sampling were done 2 times, including 1 time pretest on the first week and another on post-test on the early fourth week with a 3-day interval after intervention. This song was made to listen on the second and third week for intervention group. While the control group uses the hospital's standards without music that was used in intervention' respondents.

The anxiety variable was measured using the Hamilton Anxiety Rating Scale instrument (HARS). The researcher did not test the instrument due to existing anxietybased research using similar instrument. Shear et al. (2001) said that validity and reliability testing should be done to prove the accuracy of the instrument. The result shows that the instrument has a quite high reliability level $(0.81)$ with the scale correlation interval 0.65 , and validity as high as 0.77 . Naviati (2010) uses the instrument which has been translated into Indonesian using validity test as high as 0.92 , meaning that the item in the instrument is valid.

The result of data normality pre- and postintervention to the control and intervention group is distributed normally. Therefore, to see the average score difference before and after on both groups, we use paired t test. To measure the average score difference of anxiety level on both groups we use independent $t$ test.

The therapy of Sundanese kacapi suling music "Ayun Ambing" aims at easing 
Mustopa Saepul: The Effects of Sundanese Kacapi Suling “Ayun Ambing” Music Therapy

anxiety and stress, triggering relaxed state of mind, reducing depression and overcoming insomnia. The music is not limited to the psychological problem only but can also be applied to patients with medical, surgical, and terminal illness.

\section{Result}

Based on the general characteristics of the respondents in Table 1, the control and intervention group are dominated by results from late adults (41-60 years old), female, highschool graduates, undergoing hemodialysis for 7-12 months. The result of homogeneity test by using Chi Square testbased on the appropriate assumption-- for all aspects of characteristics obtains the value of $\mathrm{p}>0.05$, meaning that the characteristics in both groups are similar.

Table 2 shows the pre-intervention anxiety level control and intervention group with moderate $(82.2 \%$ and $100 \%)$ and significantly not different from the $p$ value $=0.325(\mathrm{p}>0.05)$. The anxiety level after the intervention in control group is mostly moderate $(69.9 \%)$, then not anxious (17.4\%). Meanwhile, on the intervention group, a decrease on the anxiety level occurs as most of them are not anxious $(56.5 \%)$, then moderate $(26.1 \%)$. The result after the intervention is significantly different between the intervention and the control group with $\mathrm{p}=0.000(\mathrm{p}<0.005)$.

The paired $t$ test on table 3 shows a significant difference on the average anxiety level before and after on the control group with $\mathrm{p}<0.05$. Such decrease is apparent on the control group (Picture 1) where red line and blue line intersect and sometimes overlap.

Picture 1 Difference of respondents's anxiety before and after intervention on the control group

shows a significant average difference of anxiety before and after the intervention of music "Ayun Ambing" on the intervention gorup with $p<0.05$. The decrease of anxiety score is also apparent in Picture 2 where the red line and blue line are far from each other.

Table 5 shows that, based on the comparative test result using independent $t$ test, there is an average difference on anxiety before on the control and intervention group with $\mathrm{p}<0.05$. This indicates a significant

Table 1 Distribution of Frequency, Percentage and Homogeneity Test of Respondents on Control and Intervention Group (46)

\begin{tabular}{|c|c|c|c|c|c|}
\hline \multirow{2}{*}{ Characteristics } & \multicolumn{2}{|c|}{$\begin{array}{c}\text { Control Group } \\
(n=23)\end{array}$} & \multicolumn{2}{|c|}{$\begin{array}{c}\text { Intervention Group } \\
(\mathrm{n}=\mathbf{2 3})\end{array}$} & \multirow{2}{*}{$p$} \\
\hline & f & $\%$ & f & $\%$ & \\
\hline \multicolumn{6}{|l|}{ Gender } \\
\hline Male & 10 & 43.5 & 7 & 30.3 & 0.359 \\
\hline Female & 13 & 56.5 & 16 & 69.6 & \\
\hline \multicolumn{6}{|l|}{ Age (old) } \\
\hline$<20$ years & 0 & & 0 & & \\
\hline $20-40$ years & 6 & 26.0 & 4 & 17.4 & \\
\hline $41-60$ years & 10 & 43.5 & 12 & 52.2 & 0.558 \\
\hline$>60$ years & 7 & 30.4 & 7 & 30.4 & \\
\hline \multicolumn{6}{|l|}{ Education } \\
\hline Elementary & 6 & 26.1 & 8 & 3.8 & \\
\hline Middle & 5 & 21.7 & 2 & 8.7 & 0.651 \\
\hline High & 7 & 30.5 & 8 & 34.8 & \\
\hline University & 5 & 21.7 & 5 & 21.7 & \\
\hline \multicolumn{6}{|l|}{ Length of Therapy (months) } \\
\hline$<6$ & 4 & 17.4 & 2 & 8.7 & \\
\hline
\end{tabular}


Mustopa Saepul: The Effects of Sundanese Kacapi Suling “Ayun Ambing” Music Therapy

\begin{tabular}{rccccc}
\hline $7-12$ & 12 & 52.2 & 11 & 47.8 & 0.951 \\
$>12$ & 7 & 30.4 & 10 & 43.5 & \\
\hline "Chis square & & &
\end{tabular}

Table 2 Comparison of Frequency on Anxiety Level of Respondents in Control and Intervention Group

\begin{tabular}{|c|c|c|c|c|c|c|c|c|c|c|c|c|c|}
\hline \multirow{3}{*}{ Measurement } & \multicolumn{6}{|c|}{ Group Control } & \multicolumn{6}{|c|}{ Group } & \multirow{3}{*}{$p$} \\
\hline & \multicolumn{2}{|c|}{ Not anxious } & \multicolumn{2}{|c|}{ Light } & \multicolumn{2}{|c|}{ Moderate } & \multicolumn{2}{|c|}{$\begin{array}{c}\text { Not } \\
\text { anxious }\end{array}$} & \multicolumn{2}{|c|}{ Light } & \multicolumn{2}{|c|}{ Moderate } & \\
\hline & f & $\%$ & f & $\%$ & f & $\%$ & $\mathbf{f}$ & $\%$ & f & $\%$ & $\mathbf{f}$ & $\%$ & \\
\hline Before & 0 & 0 & 4 & 17.4 & 19 & 82.6 & 0 & 0 & 0 & 0 & 23 & 100 & 0.125 \\
\hline After & 4 & 17.4 & 3 & 13.0 & 16 & 69.6 & 13 & 56.5 & 4 & 17.4 & 6 & 26.1 & 0.000 \\
\hline
\end{tabular}

Table 3 Average Difference of Respondents's Anxiety Before and After on The Control Group

\begin{tabular}{ccccc}
\hline Time & Mean & SD & T & p \\
\hline Before & 20.26 & 2.490 & 6.676 & 0.000 \\
After & 18.13 & 3.065 & & \\
\hline
\end{tabular}

*paired t test

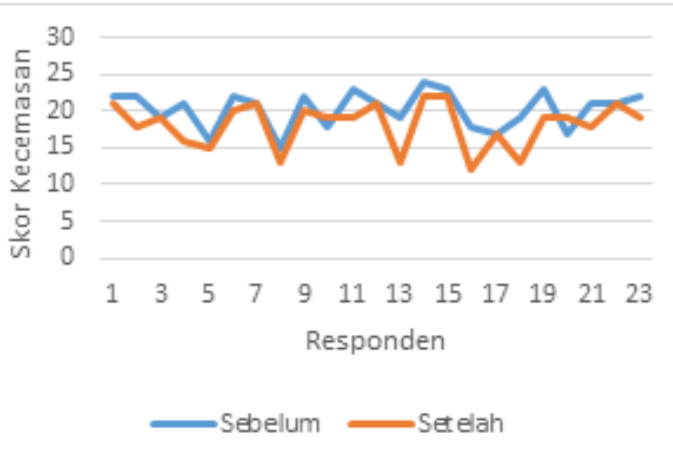

Picture 1 Difference of Respondents's Anxiety Before and After Intervention on The Control Group

Table 4 Average Difference of Respondents's Anxiety Before and After on The Intervention Group

\begin{tabular}{ccccc}
\hline Time & Mean & SD & t & p \\
\hline Before & 20.83 & 1.800 & 10.271 & 0.000 \\
\hline After & 12.87 & 4.948 & & \\
\hline
\end{tabular}

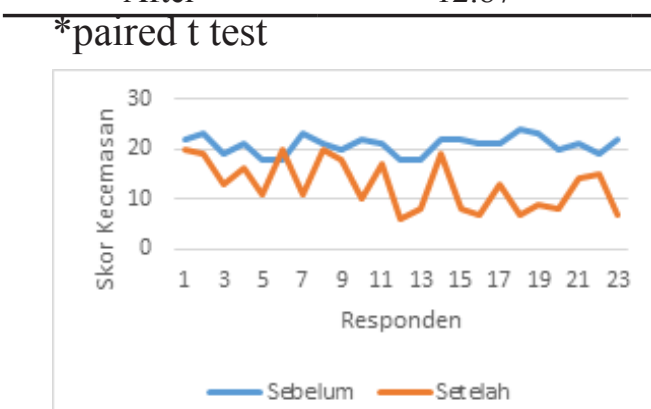

Picture 2 Difference of Respondents's Anxiety Before and After Intervention on the Intervention Group 
Mustopa Saepul: The Effects of Sundanese Kacapi Suling “Ayun Ambing” Music Therapy

Table 5 Average Difference of Respondents's Anxiety Before Iintervention Between Control and Intervention Group

\begin{tabular}{ccccc}
\hline Time & Mean & SD & t & p \\
\hline Control & 20.26 & 2.940 & 0.882 & 0.050 \\
Intervention & 20.83 & 1.800 & & \\
\hline "independent tets & & & &
\end{tabular}

Table 6 Average Difference on Respondents's Anxiety Level after the Intervention between Control and Intervention Group

\begin{tabular}{ccccc}
\hline Time & Mean & SD & $\mathbf{t}$ & $\mathbf{p}$ \\
\hline Control & 18.13 & 3.06 & 3.509 & 0.000 \\
Intervention & 12.87 & 4.95 & & \\
\hline "Independent t test & & & &
\end{tabular}

Table 7 Difference of Average Margin Change on Respondents's Anxiety after Intervention Between Control and Intervention Group

\begin{tabular}{ccccc}
\hline Time & Mean & SD & t & p \\
\hline Control & 2.13 & 2.32 & 4.839 & 0.000 \\
Intervention & 7.96 & 5.29 & & \\
\hline
\end{tabular}

average difference on anxiety before the intervention of "Ayun Ambing" music to both groups.

Table 6 shows that, based on comparative test results using independent $t$ test, there is an average difference on anxiety after on the control group and intervention groupw ith $\mathrm{p}<0.05$. This indicates a significant average difference on anxiety level after the intervention of "Ayun Ambing" music for both groups.

Table 7 shows that, based on comparative test results using independent $t$ test, there is an average change on anxiety after on the control group and intervention group with $p<0.05$. This indicates that the Sundanese kacapi suling "Ayun Ambing" music therapy lowers the anxiety level more significantly than standard therapies.

\section{Discussion}

The aim of this research is at identifying the effect of the Sundanese kacapi suling music "Ayun Ambing" on the anxiety level of chronic kidney disease patients undergoing hemodialysis. The result shows that decrease occurs in both groups, with higher rate in intervention than in the control group. The effects were shown on both before and after differences of both intervention groups and significant improvement values.

Table 2 in general the anxiety level on the control group on the pre-measurement, the majority $(82.6 \%)$ experience anxiety followed by light $(17.4 \%)$ while the value has shown that most has undergone moderate anxiety (69.6\%), not anxious (17.4\%) and light $(13.0 \%)$. Based on the values before and after, it is found out that there is a decreasing anxiety level change in the control group.

However, the average anxiety level after the intervention is relatively stable. The decrease is only slight. Table 3 shows that change. Larasati (2012) claims that the slow decrease of anxiety level in the control group may be caused by some factors such as the possibility of the respondent for not liking the song in particular and losing focus while therapy, thus resulting poorly. Moreover, Firman (2012) said that another cause is that the patients fears medical equipments such as hemodialysis machine and syringe, that the patients basically are not interested in the song in particular and excessive pain during treatment (particularly around the fistulae area).

The anxiety level before the intervention group is moderate $(100 \%)$. The value after the intervention group mostly is not anxious $(56.5 \%)$, then moderate $(26.1 \%)$, and light 
Mustopa Saepul: The Effects of Sundanese Kacapi Suling “Ayun Ambing” Music Therapy

(17.4\%). Generally, the result of research shows that in the intervention group, there is a larger decrease in the anxiety score compared to the group control. According to the result of the research analysis, there is a contribution of the "Ayun Ambing" music for the intervention group in overcoming anxiety. Previous research, too, claims similar view, concerning a lower patient's thorough participation rather than a completely inactive participation (Firman, 2012). In this research, there are few respondents with huge decrease of anxiety. Table 4 shows the average change, enabling the respondents to feel comfortable with the "Ayun Ambing" music when listening to it. The respondents are free to think and recall their past experiences that make them happy to make them relaxed and anxiety level lowered. This is in line with what Kurdita (2015) has said that the "Ayun Ambing" music makes them feel relaxed, peacful, emotionally and spiritually stable, and psychologically intact.

Table 5 shows the analysis result using independent $t$ test, where there is a significant avergae difference pre-measurement on the control and intervention group with $p$ value $<0.05 \%$. The result of this research says that the majority of respondents who have not been given intervention the "Ayun Ambing" music, experience anxiety on a moderate level.

McGrandles and McCaig (2010) claim that the anxiety is made available for individuals to focus on important problems and cast aside other things so that the person has a selective and directed concern. The anxiety is caused by many factors. Baraz et al. (2013) said that patients undergoing hemodialysis for more than 20 times often experience anxiety due to vascular access problem, the length of hemodialysis and the following effects, which include muscle cramp, hypotence, headache, and breast pain. On the other hand, according to Leghari et al. (2015), the anxiety comes due to personality reasons, an A-type person will be more likely to experience anxiety than a B-type person.

Veerapan, Arvind, and Ilayabharthi (2012) claim that other causes include change of self concept, self-control loss, and fear of future due to illness complication, and fizzling of work performance. This is also similar to
Zachariah and Gopalkrishnan's arguments (2012), claiming that the anxiety experienced by these patients are caused by asthma, pain around the fistulae area, anxiety of the illness condition and of whether the illness cannot be cured, and fear of death.

The analysis on the table 6 using independent $t$ test, there is a significant average difference aftern the intervention of the "Ayun Ambing" music on the control and intervention group with $\mathrm{p}$ value $<0.05$. There is an average decrease anxiety level due to the relaxation response that occurs during the therapy. The traditional music is complementary toward phramacological therapy, retaining aesthetics and therapeutic aspect, which is able to relax and rejuvenate the patient's physiology condition and bring back their mood in good places (Supriadi, Hutabarat \& Monica, 2015). One of the benefits of Sundanese music is that it overcomes anxiety and increases positive feelings for both medical and surgical patients (Dian, 2014).

Moreover, the average decrease of anxiety level may be caused by such factor as social support, seen as a coping mechanism, where the presence of other people help someone reduce anxiety and distraction from the hospital (hemodialysis room) and the healthcare providers; these all may affect one's way of thinking (Klaric et al., 2009). It has been proven that when the researcher conducts a research, the respondents were waited by their family members or friends, but some were not.

The independent $t$ test result shows that there is a significant difference in the average decrease of anxiety level between the group that has been made to listen the "Ayun Ambing" music and the group that obtain standard hospital therapy with the value of $0.000(p<0.05)$. A bigger average decrease of anxiety occurs in the intervention group due to the occurring relaxation effects during the therapy. The patients seemed comfortable and less anxious or painful during hemodialysis because the music helps them control their breath, heart rate, brainwave rate and revives emotional and physiological condition (Supriadi, Hutabarat and Monica, 2015). The result of this research also is similar to that of Firman's (2012), that the "Ayun Ambing" 
Mustopa Saepul: The Effects of Sundanese Kacapi Suling “Ayun Ambing” Music Therapy

music therapy proves effective to lower the anxiety level of patients prior to operation.

Larasati (2012) says that the patients were given the "Ayun Ambing" music, resulting in creating the feeling of happiness, stimulating sympathetic nerves, thus accelerating recovery over patient's stress. The anxiety experienced by the patients may improve stimulation toward the sympathetic nerve systems, repair respiratory system, maintain the need of oxygen and miocardial stimulation through traditional music. It is believed that such music synchronizes well with the hemodialysis machine, resulting in a peaceful state of mind (Firman, 2010).

\section{Conclusion}

The conclusion of this research is that there is a significant effect from the Sundanese kacapi suling music "Ayun Ambing" as a therapy to lower the anxiety level of chronic kidney disease patients undergoing hemodialysis. The results show that there is a change on anxiety level using the music therapy rather than standard therapy. The music therapy is used as one of the treatment media or alternative therapy, knowing that it has the power to cure illness and improve one's thinking ability.

\section{References}

Anastasia, S., Bayhakki, \& Nauli, A.F. (2015). Pengaruh aromaterapi inhalasi lavender terhadap kecemasan pasien gagal ginjal kronis yang menjalani hemodialisis. JOM, 2(2), 79-89.

Baraz, S., Parvardeh, S., Mohammadi, E., \& Broumand, B. (2010). Dietary and fluid compliance: An educational intervension for patients having hemodialysis. Journal of Advanced Nursing, 66(1), 60-68.

Cantekin, I., \& Tan, M. (2013). The influence of music therapy on perceived stressors and anxiety levels of hemodialysis patients. Renal Failure, 35(1), 105-109.

Cukor, D., Coplan, J., Brown, C., Friedman,
S., Cromwell-Smith, A., Peterson, R.A., \& Kimmel, P.L. (2008). Depression and anxiety in urban hemodialysis patients. Clin $J \mathrm{Am}$ Soc Nephro, 2(3), 484-90.

Damayanti, T.E. (2016). Sundanese traditional music, West Java, Indonesia. Jurnal Sekolah Tinggi Seni Indonesia (STSI) Bandung, 15(1), 18-31. DOI: 10.1051/ matecconf/20166600108.

Dian, A. (2014). Pengaruh terapi musik tradisional dan progresive muscle realxation terhadap mual muntah pasien kanker payudara yang dilakukan kemoterapi di RSUP Hasan Sadikin (Tesis). Fakultas Ilmu Keperawatan, Universitas Padjadjaran, Bandung.

Fauzi, A.N., Lestari, P., \& Pranowowati, P. (2016). Pengaruh hipnoterapi terhadap tingkat kecemasan pada pasien gagal ginjal kronis yang akan menjalani hemodialisis di RST Dr Soedjono Magelang Tahun 2016. Nama jurnalnya apa?, Volume 18, Issue 2, 82-90.

Finnegan, J., Jennifer, T., \& Veronica, J. (2013). The psychosocial experience of patients with end-stage renal disease and its impact on quality of life: findings from a needs assessment to shape a service. ISRN Nephrology, 308986. doi: $10.5402 / 2013 / 308986$.

Firman, A. (2012). Efektivitas terapi musik sunda kacapi suling dan terapi musik klasik terhadap penurunan tingkat kecemasan pasien pra operasi di RS Cibabat Cimahi. Jurnal Ilmiah Kesehatan, V(2).

Gorji, H.M., Davanloo, A., \& Heidarigorji, A. (2014). The efficacy of relaxation training on stress, anxiety, and pain perception in hemodialysis patients. Indian Journal of Nephrology, 24(6), 356-361. doi:http:// dx.doi.org/10.4103/0971-4065.132998.

Holly, Crosby, \& Carol. (2006). Music therapy as a nursing intervention. Journal of Psychological Nursing \& Mental Health, 35(3), ProQuest pg. 34.

Huang, S., Good, M., \& Zauszniewski, 
Mustopa Saepul: The Effects of Sundanese Kacapi Suling “Ayun Ambing” Music Therapy

J.A. (2010). The effectiveness of music in relieving pain in cancer patient: A randomized controlled trial. International Journal of Nursing Studies, 47, 1354-1362.

Klaric, M., Letica, I., Petrov, B., Tomic, M., Ludvig, \& Franciskovic, T. (2009). Depression and anxiety in patients on chronic hemodialysis in University Clinical Hospital Mostar. Journal of Psychiatric University of Mostar, 33(2), 153-158.

Kurdita, E. (2015). Penerapan teknik kacapi suling pada lagu tembang sunda ayun ambing. FPSD Universitas Pendidikan Indonesia, $1(1)$.

Larasati, M.F. (2012). Efektifitas terapi musik tradisional dan musik klasik terhadap tingkat kecemasan pasien pre operasi hernia inguinalis. Jurnal Kesehatan, 12(3), 123-134.

Leghari, N.U., Amin, R., Akram, B., \& Asadullah, M.A. (2015). Hemodyalisis psicosocial stressors in patients undergoing. Professional Med J Original Prof-2778, 22(6), 762-766.

Lengga, V.M. (2015). Pengaruh terapi musik tradisional terhadap penurunanan tekanan daraha pada pasien hipertensi primer (Tesis). UNPAD, Bandung.

Macharon. G., Fahed. M., Matar. D., BouKhalil. R., Kazour. F., Nehme-Chlela. D., \& Richa, S. (2014). Anxiety, depression and suicidal ideation in Lebanese patients undergoing hemodialysis. Community Ment Health J., 50, 235-238. DOI 10.1007/ s10597-013-9669-4.

Martinez, J. (2009). Is music therapy?. Nephrology Nursing Journal, 36(3), 329421. Retrieved from http://search.proquest. $\mathrm{com} /$ docview $/ 216545686$ ? accounted $=48290$.

Mahdavi, A., Gorji, M.A.H., Gorji, A.M.H., Yazdani, J., \& Ardebil, M.D. (2013). Implementing benson's relaxation training in hemodialysis patients: Changes in perceived stress, anxiety, and depression. North American Journal of Medical Sciences, 5(9), 536-40. doi:10.4103/1947-2714.118917.
McGrandles, A., \& McCaig, M. (2010). Diagnosis and management of anxiety in primary care. Nurse Precribing, 8(7), 310-18.

Mollahadi, M., Tayyebi, A., Ebadi, A., \& Daneshmandi, M. (2010). Comparison of anxiety, depression and stress among hemodialysis and kidney transplantation patients. Iranian Journal of Critical Care Nursing Winter, 2(4), 153-156.

Namawi, Q. (2013). Populasi penderita gagal ginjal terus meningkat di 2013. http://health. okezone.com/read/201 3/06/28/482/829210/ redirect diunduh pada tanggal 22 Oktober 2013.

Naviati, E. (2010). Hubungan dukungan perawat dengan tingkat kecemasan orang tua di ruang rawat inap RSB Harapan Kita Jakarta (Tesis). Fakultas Ilmu Keperawatan, Universitas Indonesia, Jakarta.

Patimah, I., Suryani, \& Nuraeni, A. (2015). Pengaruh relaksasi dzikir terhadap tingkat kecemasan pasien gagal ginjal kronis yang menjalani hemodialisa. Jurnal Keperawatan Padjadjaran, 3(1).

Sari, N., \& Hisyam, B. (2015). Hubungan antara diabates melitus tipe II dengan kejadian gagal ginjal kronik di RS PKU Muhamamdiyah Yogyakarta periode Januari 2011-Oktober 2012. JKKI, 6(1).

Shear, M., Katherine, M.D., Joni, V.B., Paola, R.D., Stat, J. E., Bruce, L.M.D., Michael, W. O., Mark H.P., Linda, C., Jenna, W.B.S, Arjumand, A., \& David, M.F. (2001). reliability and validity of a structured interview guide for the hamilton anxiety rating scale (SIGH-A). Depression and Anxiety, 13(4), 166-178, 2001.

Supriadi, D., Hutabarat, E., \& Monica, V (2015). Pengaruh terapi musik tradisional kecapi suling sunda terhadap tekanan darah pada lansia dengan GGK. Jurnal Skolastik Keperawatan, 1(2). ISSN: 2443-0935. E-ISSN: 2443-1699.

Veerapan I., Arvind R.M., \& Ilayabharthi V. (2012). Predictors of quality of life 
Mustopa Saepul: The Effects of Sundanese Kacapi Suling “Ayun Ambing” Music Therapy

of hemodialysis patients in India. Indian Journal of Nephrology, 22(01), 18-25. DOI 10.4103/0971-4065.91185.

Wang, L., \& Chen, C. (2009). The psychological impact of hemodialysis on patients with chronic renal failure. Departement of Psychiatry Chang Gung Memorial Hospital: Taiwan.
Zachariah, L., \& Gopalkrishnan, S. (2014). Impact of music therapy during hemodialysis on selected physiological parameters of patients undergoing hemodialysis in selected hospitals. International Journal of Comprehensive Nursing, 1(2). ISSN: 23495413. http://ijcn.mainspringer.com. 